\title{
Helminths of the frog Pleurodema diplolister (Anura, Leiuperidae) from the Caatingain Pernambuco State, Northeast Brazil
}

\author{
Teles, DA. ${ }^{a}$, Sousa, JGG. ${ }^{a *}$, Teixeira, AAM. ${ }^{a}$, Silva, MC. ${ }^{a}$, Oliveira, \\ RH. ${ }^{a}$, Silva, MRM. ${ }^{a}$ and Ávila, $R W^{b}$
}

\begin{abstract}
aPrograma de Pós-Graduação em Bioprospecção Molecular, Departamento de Química Biológica, Universidade Regional do Cariri - URCA, Rua Cel. Antônio Luiz, 1161, Campus do Pimenta, CEP 63105-000, Crato, CE, Brazil

bDepartamento de Ciências Biológicas, Universidade Regional do Cariri - URCA, Rua Cel. Antônio Luiz, 1161, Campus do Pimenta, CEP 63105-000, Crato, CE, Brazil

*e-mail: sousajgg@gmail.com
\end{abstract}

Received: May 22, 2013 - Accepted: December 12, 2013 - Distributed: March 31, 2015

\section{Introduction}

The leiuperid genus Pleurodema (Tshudi, 1838) currently comprises 15 species widely distributed in the Neotropical region (Frost, 2011), mainly in dry forests and open areas (Ferraro and Casagranda, 2009; Kolenc et al., 2009). Pleurodema diplolister (Peters, 1870) is the only species in the genus known to inhabit the Caatinga biome (shrub-like vegetation) (Cardoso and Arzabe, 1993). The species is also found in the Brazilian Cerrado and CerradoCaatinga transition zones (Andrade and Vaz-Silva, 2012).

Pleurodema diplolister is a fossorial and omnivorous frog, and its explosive reproduction shows greater specialization between the anuran communities of the Caatinga (Hödl, 1992; Cardoso and Arzabe, 1993; Santos et al., 2003).

Parasitological studies are important to understand host population dynamics, as well behavioral, morphological and dietary shifts, especially within highly specialized anurans such as $P$. diplolister. To date, only two records of parasitism in the genus Pleurodema are available, all of these by nematodes of the family Cosmocercidae: Aplectana meriodionalis Lent and Freitas, 1948 infecting Pleurodema borellii Peracca, 1895 (Baker, 1980) and Oxyascaris oxyascaris Travassos, 1920 in P. diplolister (Vicente et al., 1990).

Herein, we present data on helminth infection of the frog P. diplolister in the Caatinga of Pernambuco State, Brazil.

\section{Material and Methods}

The study was conducted onAngico Farm $\left(08^{\circ} 07^{\prime}\right.$ 55.7 " S $40^{\circ} 05^{\prime} 3.2$ " W), located in the rural zone of the municipality of Ouricuri, in the Caatinga of Pernambuco State. The vegetation is characterized mainly by deciduous forest and hypoxerophytic Caatinga (CPRM, 2005).

Pleurodema diplolister specimens were collected in February 2012, using pitfall traps with drift fence or by hand, in a gallery forest near a temporary river after one of the few rains occurring that year. The specimens were euthanatized with a lethal injection of lidocaine, fixed in 10\% formalin and then stored in $70 \%$ ethanol. The snout-vent length was measured with a digital caliper $( \pm 0.01 \mathrm{~mm})$. Sex was assigned by the direct examination of the gonads.
Voucher specimens were deposited at Coleção Herpetológica da Universidade Regional do Cariri, Crato municipality, Ceará State (URCA-H: 2855-2858, 2866-2870).

Lungs, gall bladder and digestive tract were examined under a stereomicroscope for parasites. For identification, nematodes were cleared in lactophenol, and the cestodes were stained with carmine, dehydrated in an increasing alcohol series and cleared in creosote, where they were subsequently mounted on temporary slides and identified under a light microscope. All parasites were counted and stored in $70 \%$ ethanol. Voucher specimens were deposited in the Coleção Parasitológica da URCA (URCA-P: 357-359, 379-381).

Prevalence and mean intensity of infection were calculated according to Bush et al. (1997). A Pearson correlation $(R)$ was conducted to determine the relationship between snout-vent length (SVL) and number of parasites using R software (R Development Core Team, 2013). The discrepancy index (D) was used to measure the level of aggregation of each helminth species, as suggested by Poulin (1993). This index was calculated with the software Quantitative Parasitology 3.0 (Rozsa et al., 2000).

\section{Results}

A total of 32 specimens of P. diplolister were examined, which included 11 males $(33.04 \pm 1.29 \mathrm{~mm} \mathrm{SVL})$ and 21 females ( $34.6 \pm 1.71 \mathrm{~mm} \mathrm{SVL})$. Two helminth species were found infecting the intestines of $P$. diplolister from the Caatinga of Pernambuco State: Raillietnema spectans Gomes, 1964 (Nematoda: Cosmocercidae) and Plerocercoid larvae of the family Proteocephalidae (Cestoda). These larvae could not be identified due to the immature condition.

Of the total anuran hosts examined, six of them harbored at least one helminth species (overall prevalence of $18.75 \%$; mean intensity of infection of $10 \pm 13.59$ ). For $R$. spectans, the prevalence was $15.6 \%$ and for the plerocercoid cestode larvae $3.1 \%$. The prevalence was $19.4 \%$ for female hosts and $18.2 \%$ for males. Mean intensity of infection was 14.3 for females and 1 for males. Discrepancy index $(D)$ was 0.901 for $R$. spectans and 1 for the cestode larvae. 


\section{Discussion}

Helminth communities of amphibians are characterized by generalist species (Aho, 1990). The low host specificity, allied to the general lack of studies with Neotropical frog species, frequently are the main causes of new host records. In Brazil, species of Leptodactylidae and Bufonidae may be considered as hosts for a generalist helminth fauna, in view of studies conducted so far (Vicente et al., 1990, Goldberg et al., 2007, 2009; Luque et al., 2005). Regarding others amphibians taxa, further studies is still required to have any conclusion about the host specificity.

The leiuperid $P$. diplolister is a new host record for the cosmocercid R. spectans and for the proteocephalidean cestode. In Brazil, $R$. spectans is known to infect the bufonids Rhinella crucifer (Wied-Neuwied, 1821), Rhinella icterica (Spix, 1824), and Rhinella schneideri (Werner, 1894) and the leptodactylid Leptodactylus latrans (Steffen, 1815) (Vicente et al., 1990).

Cestodes of the family Proteocephalidae are endoparasites of vertebrates, infecting mainly freshwater fishes (Pavanelli and Santos, 1991). It is also found in anurans of the families Leptodactylidae in Chile and Peru (Olmos and Muñoz, 2006; Iannacone, 2003), Bufonidae in Peru (Tantaleán and Garcia, 1989), Hylidae in Ecuador (Dyer and Altig, 1977), and Ranidae in Costa Rica (Bursey and Goldberg, 2006) and Papua New Guinea (Bursey et al., 2008).

Brazil harbors a high diversity of amphibians with 946 species (Segalla et al., 2012). Despite this great diversity, parasitological studies focusing on ecological aspects, such as helminth community structure are scarce. Although there has been an increase in such studies in the past few years (Luque et al., 2005; Campião et al., 2009), further efforts are still necessary to understand the influence of parasites in the structure and dynamics of Brazilian anuran populations.

\section{Acknowledgements}

We thank Pró-Reitoria de Pós Graduação e Pesquisa da Universidade Regional do Cariri for financial support (Chamada Pública PRPGP-URCA 03/2013). To Fundação Cearense de Apoio ao Desenvolvimento Científico e Tecnológico - FUNCAP for the research grant awarded to RWA(BPI-0067-00006.01.00/12) and fellowship to JGGS. To Coordenação de Aperfeiçoamento de Pessoal de Nível Superior - CAPES for the fellowship to DAT and MRMS, such as by Instituto Chico Mendes de Conservação da Biodiversidade - ICMBio (permit 29613-1) for support. We are grateful to João A. Araujo-Filho for laboratory assistance. Dr. A. Leyva helped with English editing of the manuscript.

\section{References}

AHO, JM., 1990. Helminth communities of amphibians and reptiles: comparative approaches to understanding patterns and process. In ESCH, GW., BUSH, AO. and AHO, JM. (Eds.). Parasite communities: patterns and process. London: Chapman and Hall. p. 157-199. http://dx.doi.org/10.1007/978-94-009-0837-6_7.

ANDRADE, SP. and VAZ-SILVA, W., 2012. First state record and distribution extension of Pleurodema diplolister (Peters 1870) (Anura: Leiuperidae) from state of Goiás, Brazil. Check List, vol. 8. no. 4, p. 149-151

BAKER, MR., 1980. Revision of old World species of the genus Aplectana Railliet \& Henry, 1916 (Nematoda, Cosmocercidae). Bulletin du Museum National d'Histoire Naturelle, vol. 2, p. 955-998.

BUSH, AO., LAFFERTY, KD., LOTZ, JM. and SHOSTAK, AW., 1997. Parasitology meets ecology on its own terms: Margolis et al. revisited. The Journal of Parasitology, vol. 83, no. 4, p. 575-583. http://dx.doi.org/10.2307/3284227. PMid:9267395

BURSEY, CR. and GOLDBERG, SR., 2006. New species of Raillietnema (Nematoda: Cosmocercidae) and other helminths in Rana vibicaria (Ranidae) from Costa Rica. Comparative Parasitology, vol. 73, no. 2, p. 193-200.

BURSEY, CR., GOLDBERG, SR. and KRAUS, F., 2008. A new species of Proteocephalus (Cestoda: Proteocephalidae), description of the male of Desmognathinema papuensis (Nematoda: Quimperiidae), and other endoparasites in Sylvirana supragrisea (Anura:Ranidae) from Papua New Guinea. Comparative Parasitology, vol. 75, no. 1, p. 33-48. http://dx.doi.org/10.1654/4291.1.

CAMPIÃO, KM., SILVA, RJ. and FERREIRA, VL., 2009. Helminth parasites of Leptodactylus podicipinus (Anura: Leptodactylidae) from south-eastern Pantanal, State of Mato Grosso do Sul, Brazil. Journal of Helminthology, vol. 83, no. 4, p. 345-349. http://dx.doi. org/10.1017/S0022149X09289358. PMid:19422730

CARDOSO, AJ. and ARZABE, C., 1993. Corte e desenvolvimento larvário de Pleurodema diplolistris (Anura: Leptodactylidae). Revista Brasileira de Biologia = Brazilian Journal of Biology, vol. 53 , no. 4 , p. $561-570$

CPRM, 2005. Diagnóstico do município de Ouricuri. Brasília. Available from: $<$ http://www.cprm.gov.br>. Access in: 12 Apr. 2012.

DYER, WG. and ALTIG, R., 1977. Ophiotaeniaolseni sp. n. (Cestoda: Proteocephalidae) from Hyla geographica Spix 1824 in Ecuador. The Journal of Parasitology, vol. 63, no. 5, p. 790792. http://dx.doi.org/10.2307/3279879.

FERRARO, DP. and CASAGRANDA, MD., 2009. Geographic distribution of the genus Pleurodema in Argentina (Anura: Leiuperidae). Zootaxa, vol. 2024, p. 33-55.

FROST, DR., 2011. Amphibian Species of the World 5.5, an Online Reference. Electronic Database. New York: American Museum of Natural History. Available from: $<\mathrm{http}: / /$ research. amnh.org/vz/herpetology/amphibia>.

GOLDBERG, SR., BURSEY, CR., CALDWELL, JP., VITT, LJ. and COSTA, GC., 2007. Gastrointestinal helminths from six species of frogs and three species of lizards, sympatric in Pará State, Brazil. Comparative Parasitology, vol. 74, no. 2, p. 327-342. http://dx.doi.org/10.1654/4268.1

GOLDBERG, SR., BURSEY, CR., CALDWELL, JP. and SHEPARD, DB., 2009. Gastrointestinal Helminths of Six Sympatric Species of Leptodactylus from Tocantins State, Brazil. Comparative Parasitology, vol. 76, no. 2, p. 258-266. http:// dx.doi.org/10.1654/4368.1.

HÖLD, W., 1992. Reproductive behavior in the neotropical foam-nesting frog Pleurodema diplolistris (Leptodactylidae). Amphibia-Reptilia, vol. 13, no. 3, p. 263-274. http://dx.doi. org/10.1163/156853892X00472. 
IANNACONE, J., 2003. Helminth parasites of Telmatobius jelskii (Peters) (Anura, Leptodactylidae) from Lima, Peru. Revista Brasileira de Zoologia, vol. 20, no. 1, p. 131-134.

KOLENC, F., BORTEIRO, C., BALDO, D., FERRARO, DP. and PRIGIONI, C. 2009. The tadpoles of Pleurodema bibroni Tschudi and Pleurodema kriegi (Müller), with notes on their advertisement calls, natural history and conservation status (Amphibia, Anura, Leiuperidae). Zootaxa, vol. 1969, p. 1-35.

LUQUE, JL., MARTINS, AN. and TAVARES, LER., 2005. Community structure of metazoan parasites of the yellow Cururu toad, Bufo ictericus (Anura, Bufonidae) from Rio de Janeiro, Brazil. Acta Parasitologica, vol. 50, no. 1, p. 215-220.

OLMOS, V. and MUÑOZ, G., 2006. Estado de conocimiento de los parasitos eumetazoos de organismos dulceacuicolas de Chile. Gayana Zoologica, vol. 70, no. 1, p. 122-139.

PAVANELLI, GC. and SANTOS, MHM., 1991. Proteocefalídeos parasitos de peixes, em especial pimelodídeos do rio Paraná, Paraná. Revista Unimar, vol. 13, no. 2, p. 147-162.

POULIN, R., 1993. A cleaner perspective on cleaning symbiosis. Reviews in Fish Biology and Fisheries, vol. 3, no. 1, p. 75-79. http://dx.doi.org/10.1007/BF00043298.
R Development Core Team, 2013. R: a language and environment for statistical computing. Vienna: R Foundation for Statistical Computing. http://www.R-project.org/.

RÓZSA, L., REICZIGEL, J. and MAJOROS, G., 2000. Quantifying parasites in samples of hosts. The Journal of Parasitology, vol. 86 , no. 2 , p. $228-232$. http://dx.doi.org/10.1645/00223395(2000)086[0228:QPISOH]2.0.CO;2. PMid:10780537

SANTOS, JWA., DAMASCENO, RP. and ROCHA, PLB., 2003. Feeding habits of the frog Pleurodema diplolistris (Anura, Leptodactylidae) in quaternary sand dunes of the Middle Rio São Francisco, Bahia, Brazil. Phyllomedusa, vol. 2, no. 2, p. 83-92. http://dx.doi.org/10.11606/issn.2316-9079.v2i2p83-92.

SEGALLA, MV., CARAMASCHI, U., CRUZ, CAG., GARCIA, PCA. and GRANT, T., HADDAD, CFB. and LANGONE, J., 2012. Brazilian amphibians: list of species. São Paulo. Available from: $<$ http://www.sbherpetologia.org.br>. Access in: 6 Apr. 2013.

TANTALEÁN, MV. and GARCÍA, L., 1989. Contribución al estudio de los helmintos parásitos de anfibios del Perú. Boletín de Lima, vol. 64, p. 69-78.

VICENTE, JJ., RODRIGUES, HO., GOMES, DC. and PINTO, RM., 1990. Nematóides do Brasil 2 parte: nematóides de Anfíbios. Revista Brasileira de Zoologia, vol. 7, no. 4, p. 549-626. http:// dx.doi.org/10.1590/S0101-81751990000400015. 